\title{
減圧貯蔵におけるチャンバ内ガス環境の測定
}

\author{
小野田明彦* ・大森定夫* 椎名武夫** ・星野健一***
}

\section{Measurement of Gas Components in the Low Pressure Storage Chambers}

\author{
Akihiko OnOda ${ }^{*}$, Sadao OHMORI ${ }^{*}$, Takeo Shina ${ }^{* *}$ and Kenichi Hoshino ${ }^{* * *}$ \\ * Bio-oriented Technology Research Advancement Institution (Institute of \\ Agricultural Machinery), 1-40-2, Nisshin-cho, Omiya-shi, Saitama 331 \\ ** National Food Research Institute, Ministry of Agriculture, Forestry \\ and Fisheries, Tsukuba, Ibaraki 305 \\ *** Engineering Center, Niigata Tekko Co. Ltd., 1-9-3, \\ Kamata Hon-cho, Ohta-ku, Tokyo 144
}

\begin{abstract}
Making use of tomatoes and melons, gas components in the low pressure storage chambers were analyzed using a gas sampling implement newly designed and a gas tight syringe. The $\mathrm{O}_{2}, \mathrm{CO}_{2}, \mathrm{~N}_{2}$ and $\mathrm{C}_{2} \mathrm{H}_{4}$ gases were analyzed by a gas-chromatograph. On the basis of analytical values, $\mathrm{CO}_{2}$ gas concentrations were calculated for both vegetables. Under the low pressure, the respiratory ratios of tomatoes and melons were $1 / 30 \sim 1 / 40$ and $1 / 20$, respectively, in comparison with those under the normal pressure. In view of these results, it was evident that controlled respiration of the vegetables was effectively realized in the low pressure storage chambers.

(Received May 12, 1988)
\end{abstract}

筆者らが開発した差圧式隇圧貯蔵は，低圧下で上下 2 つの圧力 $P_{1} ， P_{2}$ を設定し，経時的に両圧力間を往復 させながら眝蔵する方法である．別報”で本眝蔵方式の 特徽や，圧力を一定に保って詝蔵する定圧減圧詝蔵方式 との貯蔵性の比較について検討した結果を報告した。

ところで, 隇圧眝蔵では減圧されたチャンバ内の空気 組成や，隇圧下における青果物の生理作用等が眝蔵性を 左右する主要なファクターとなるが，前記別報の中では これらについて言及するには至らなかった，従来の研究 の中には，隇圧下の環境について測定された例が若干見 受けられる22 が，これらはいずれす定圧隇圧条件で 測定されたものである，そこで，本報では主に差圧式減 圧眝葴の眝蔵環境を把握するために行った, 減圧下のチ ヤンバ内ガス環境の測定結果について報告する.

実験では減圧下のチャンバ内から直接ガスをサンプリ
ングする方法を検討し，さらにサンプリングしたガスを 分析して，それをもとに供試品目（トマト，メロン）の 呼吸量を算出した.

\section{実 験 方 法}

\section{1. 供試野菜}

施設栽培のトマト（品種：瑞光 $102 ，$ 緑熟果，昭和 62 年 5 月 24 日収稪, 場所杤木県下都賀郡野木町佐川野) とメロン（品種: アール220, 交配 49 日後収㮃, 昭和 62 年 6 月 22 日収穫, 場所香川県三豊郡山本町大字神田) を用いた。

\section{2. 試験区及ひ館蔵温度}

両供試品目之も, 差圧減圧区之定圧減圧区を設け, 他 に比較のためトマトではデシヶータ密閉区, メロンでは ポリフィルム包装区をそれぞれ設けた。眝蔵温度はトマ

* 生物系特定産業技術研究推進機構（農業機械化研究所（干331 埼玉県大宮市日進町 1-40-2）

**農林水産省食品総合研究所（广305 茨城県つくば市観音台 2-1-2）

*** (株) 新潟鉄工所エンジニアリングセンター（厂144 東京都大田区蒲田本町 1-9-3） 
表 1 減圧試験区の眝蔵条件

\begin{tabular}{|c|c|c|c|c|c|c|c|}
\hline & $\varepsilon$ 品 & 品 & & $\begin{array}{c}\text { 設 定圧力 } \\
(\mathrm{mmHg})\end{array}$ & $\begin{array}{c}\text { 流入空気量 } \\
(\mathrm{m} l / \mathrm{min})\end{array}$ & $\begin{array}{c}\text { 排気サイクル } \\
\text { (h) }\end{array}$ & 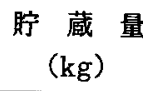 \\
\hline \multirow{2}{*}{ 差 } & $F\{1$ & $卜 \nabla$ & & \multirow{2}{*}{$100 \leftrightarrow 300$} & $3 \sim 5$ & 100 & $6.9(40)$ \\
\hline & 仕 $\{x$ & $\times$ व & ン & & 16 & 12 & $12.5(9)$ \\
\hline & F $\{1$ & $r>$ & r & \multirow{2}{*}{100} & 45 & \multirow{2}{*}{-} & $7.2(40)$ \\
\hline & $12\{x$ & $\times$ 口 & ン & & 30 & & $13.0(9)$ \\
\hline
\end{tabular}

眝蔵量の（）内は個数

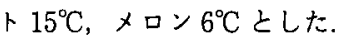

\section{3. 装置及ひ貯蔵量}

減圧の両区は内容積 $6 \times 10^{-2} \mathrm{~m}^{3}(60 \mathrm{l})$ の円筒形鋼 鉄チャンバを用いた，デシケータは内容積 $1.3 \times 10^{-2} \mathrm{~m}^{3}$ (13l) で，この中にトマトを 20 個（3.7 kg）入れた. ポリフィルムは厚さ $30 \mu \mathrm{m}$ の低密度ポリエチレンフィ ルムを用い，この中にメロンを 5 個 $(1.4 \mathrm{~kg})$ 入れて， 開口部をゴムバンドで封じた，実験は詝蔵温度に設定し た低温庫内に，各々の試験区を設置して行った，減圧区 の設定圧力，チャンバ内流入空気量等眝蔵条件及び眝蔵 量を表 1 にまとめて示した

\section{4. チャンバ内空気のサンプリング方法}

減圧下のチャンバ内から空気をサンプリングするため に，図1に示すガスサンプリング器具を試作した。 これ は，直径 $2 \mathrm{~mm}$ の穴を貫通させだサンプリング金具の 一端に，ガスのサンプリングロを兼ねたゴムパッキンを 付けて気密性をむたせ，他端にはビニールチューブをつ けてチャンバ内の任意の位置でガスをサンプリングでき るようにしたものである.この器具をチャンバに取付け， ゴムパッキンの部分からガスタイトシリンジ (PS-A 型）を挿入して，減圧下のチャンバ内から直接空気をサ ンプリングした。 サンプリングの方法は，シリンジを挿 入した後, シリンジ目盛で $0.5 \mathrm{~m} l$ 吸引した状態で止め, その状態を 5〜10 分間保持した.これはシリンジ内がチ カンバ内と同様の環境となるようにしたものである。 そ の後シリンジをロックして外気の侵入を防ぎ，分析に供 した。 サンプリング位置は, 差圧減圧区はチャンバ内中 央部，定圧減圧区は排気口とした。

\section{5. サンプリング空気の分析}

各試験区からサンプリングした空気をガスクロマトグ ラフにかけ， $\mathrm{O}_{2}, \mathrm{CO}_{2}, \mathrm{~N}_{2}$ について分析を行った. メ ロンについては $\mathrm{C}_{2} \mathrm{H}_{4}$ (エチレンガス) についても分析 を行った

(1) $\mathrm{O}_{2}, \mathrm{CO}_{2}, \mathrm{~N}_{2}$ ガスの分析

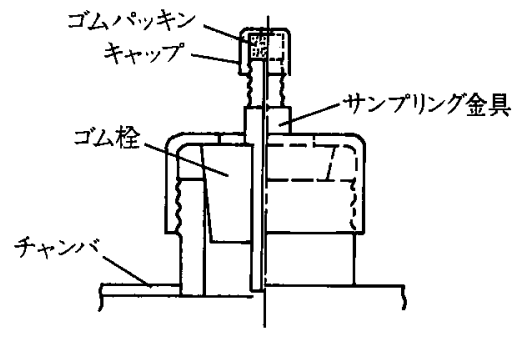

図 1 ガスサンプリング器具概要

シリンジ目盛で $0.5 \mathrm{~m} l$ サンプリングし，熱伝導度検 出器 (使用カラム: SUS $6 \phi \times 2 \mathrm{~m}$, 充填剂: WG-100, カラム温度: $50^{\circ} \mathrm{C}$, インジェクション温度: $50^{\circ} \mathrm{C}$ キャ リアガス:ヘリウム $28 \mathrm{~m} l / \mathrm{min}$ ) で分析した。 なお, 分析に際しては，各々の標準ガスを用いて検量線を作成 し，定量分析を行った，従って，減圧区の分析值は大気 圧に換算した濃度割合（\%）となっている。

(2) $\mathrm{C}_{2} \mathrm{H}_{4}$ ガスの分析

シリンジ目盛で $0.2 \mathrm{ml}$ を水素炎イオン化検出器（使 用カラム：ガラス製 $2.6 \phi \times 3 \mathrm{~m}$, 充填戍: ポリエチレ ングリコール 6000 , カラム温度 : $80^{\circ} \mathrm{C}$, インジェクシ ョン温度: $140^{\circ} \mathrm{C}$ キャリアガス: $\mathrm{N}_{2} 60 \mathrm{ml} / \mathrm{min}, \mathrm{H}_{2} 50$ $\mathrm{m} l / \mathrm{min}$, 空気 $80 \mathrm{ml} / \mathrm{min}$ ) にかけて分析した.

6. トマト,メロンの $\mathrm{CO}_{2}$ 排出量 (呼吸量) 算出

(1) 差圧減圧区

設定した 2 つの圧力 $P_{1}, P_{2}$ で， $P_{1} \longrightarrow P_{2}$ の昇圧過 程におけるある2点の圧力 $P_{\mathrm{a}}, P_{\mathrm{b}}$ についてガス分析 を行い，両圧力における $\mathrm{CO}_{2}$ 濃度の差， $P_{\mathrm{a}} \longrightarrow P_{\mathrm{b}}$ の 時間, チャンバ内容積, 眝蔵量等から次により算出した.

チャンバ内空間容積: $V_{\mathrm{e}}\left(\mathrm{m}^{3}\right)$

$$
V_{\mathrm{c}}=V-V_{\mathrm{v}}
$$

$P_{\mathrm{a}} \longrightarrow P_{\mathrm{b}}$ 間のチャンバ内空気増加量 : $Q(\mathrm{~kg})$

$$
Q=V_{\mathrm{c}} \times \rho \times\left(P_{\mathrm{b}}-P_{\mathrm{a}}\right) / \pi
$$

$Q$ の中に含まれる $\mathrm{CO}_{2}$ 量 : $c(\mathrm{~kg})$ 
$c=Q \times 0.046 \times 10^{-2}\left(0.046\right.$ は $\mathrm{CO}_{2}$ の重量\%)

$P_{\mathrm{a}} \longrightarrow P_{\mathrm{b}}$ 間の $\mathrm{CO}_{2}$ 是積排出量 $: x(\mathrm{~kg})$

$$
x=\left(C_{\mathrm{b}}-C_{\mathrm{a}}\right) \times 100^{-1} \times Q-c
$$

これから、

$$
q_{1}=x \times 10^{6} \times W^{-1} \times H^{-1}
$$

(2) 定圧減圧区

ガス分析の結果得られた $\mathrm{CO}_{2}$ 濃度から, 流入空気に 含まれる $\mathrm{CO}_{2}$ 濃度を差引いたものか呼吸によって排出 された $\mathrm{CO}_{2}$ の量と考えられるので，以下の計算によっ た.

$$
q_{2}=\rho_{\mathrm{c}} \times 10^{6} \times\left(C_{\mathrm{g}}-C_{\mathrm{s}}\right) \times 10^{-2} \times F \times 60 \times W^{-1}
$$

(3) デシケー夕密閉区

ある時間間隔をおいてガス分析を行い，その間の $\mathrm{CO}_{2}$ 増加割合と, デシケータ内空間容積, 眝蔵量等から次に より算出した.

$$
\begin{aligned}
& \text { デシケータ内空間容積 }: v_{\mathrm{c}}\left(\mathrm{m}^{3}\right) \\
& v_{\mathrm{c}}=V-v_{\mathrm{v}} \\
& q_{3}=\left(C_{\mathrm{t}_{2}}-C_{\mathrm{t}_{1}}\right) \times 10^{-2} \times v_{\mathrm{c}} \times \rho_{\mathrm{c}} \times 10^{6} \times W^{-1} \\
& \times\left(t_{2}-t_{1}\right)^{-1} \ldots \ldots \ldots \ldots \ldots \ldots \ldots \ldots \ldots \ldots \ldots \ldots \ldots
\end{aligned}
$$

(4) 常圧下におりる $\mathrm{CO}_{2}$ 排出量

各試験区の呼吸量と比較するため, 同一眝蔵温度の常 圧下における $\mathrm{CO}_{2}$ 排出量を求めた。 これは, 図 2 に示 す装置を用いて，デシケータ内を通した空気と，低温庫 内の空気とを赤外線ガス分析計に導き，両者の $\mathrm{CO}_{2}$ 濃 度の差, 吸引空気量, 眝蔵量等から次式により算出した ものである.

$$
q_{4}=\left(C_{\mathrm{d}}-C_{\mathrm{c}}\right) \times 10^{-2} \times S \times 60 \times \rho_{\mathrm{c}} \times 10^{6} \times W^{-1}
$$

[記号〕

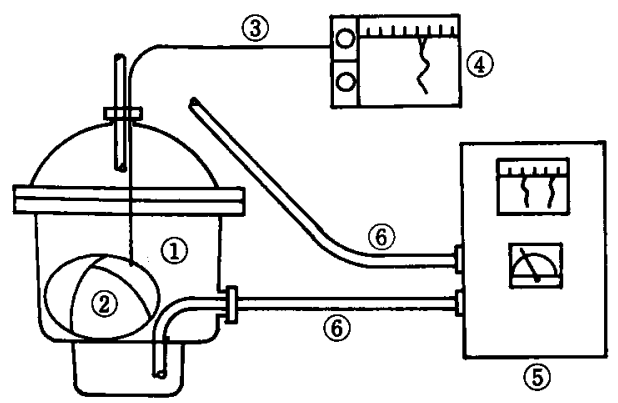

図 2 呼吸量測定装置概要

$\begin{array}{llll}\text { (1) デシケータ (2) 試料 (3) } \mathrm{C}-\mathrm{C} \text { 熱電対 } & \end{array}$

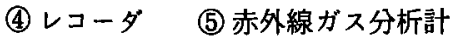

(6) ガス吸引チューブ $q_{1} \sim q_{4}$ : 単位時間・単位眝蔵量当たり $\mathrm{CO}_{2}$ 排出量 $(\mathrm{mg} / \mathrm{kg} \cdot \mathrm{h})$

$W:$ 眝蔵量 $(\mathrm{kg})$

$\pi$ : 大気圧 $(\mathrm{mmHg})$, ここでは $760 \mathrm{mmHg}$

$\rho_{\mathrm{c}}: 1 \mathrm{~atm}$ における $\mathrm{CO}_{2}$ 密度 $\left(\mathrm{kg} / \mathrm{m}^{3}\right)$

$\left(6^{\circ} \mathrm{C}\right.$ の時 $1.92,15^{\circ} \mathrm{C}$ の時 1.86$)$

$\rho: 1$ atm における空気密度 $\left(\mathrm{kg} / \mathrm{m}^{3}\right)$

$\left(6^{\circ} \mathrm{C}\right.$ の時 $1.27,15^{\circ} \mathrm{C}$ の時 1.23$)$

$V, v:$ チャンバ及びデシケータ内容積 $\left(\mathrm{m}^{3}\right)$

$V_{\mathrm{v}}, v_{\mathrm{y}}:$ 眝蔵品の占める容積 $\left(\mathrm{m}^{3}\right)$

(貯蔵品の密度を $1 \mathrm{~kg} / \mathrm{m}^{3}$ とした)

$C_{\mathrm{b}}$ : 圧力 $P_{\mathrm{b}}$ の時の $\mathrm{CO}_{2}$ 濃度 $(\%)$

$C_{\mathrm{a}}$ : 圧力 $P_{\mathrm{a}}$ の時の $\mathrm{CO}_{2}$ 濃度 $(\%)$

$H: P_{\mathrm{a}} \longrightarrow P_{\mathrm{b}}$ の時間 $(\mathrm{h})$

$C_{\mathrm{g}}$ : ガス分析の結果得られた $\mathrm{CO}_{2}$ 濃度 $(\%)$

$C_{\mathrm{s}}$ : ガスサンプリング時の圧力 $P(\mathrm{mmHg})$ におけ る $\mathrm{CO}_{2}$ 濃度 (\%) 注)

注）低温庫内の空気中の $\mathrm{CO}_{2}$ 濃度を $C_{\mathrm{n}}(\%)$ と して

$C_{\mathrm{s}}=C_{\mathrm{n}} \times P \times \pi^{-1}$ より求めた.

$F:$ 流入空気量 $\left(\mathrm{m}^{3} / \mathrm{min}\right)$

$C_{\mathrm{t}_{1}}$ : 時間 $t_{1}$ における $\mathrm{CO}_{2}$ 濃度 $(\%)$

$C_{\mathrm{t}_{2}}$ : 時間 $t_{2}$ における $\mathrm{CO}_{2}$ 濃度 $(\%)$

$t_{1}, t_{2}$ ：ガスをサンプリングした時間（h）

$C_{\mathrm{d}}$ : デシケータ内を通した空気の $\mathrm{CO}_{2}$ 濃度 $(\%)$

$C_{\mathrm{c}}$ : 低温庫内空気の $\mathrm{CO}_{2}$ 濃度 $(\%)$

$S:$ 吸引空気量 $\left(\mathrm{m}^{3} / \mathrm{min}\right)$

\section{実験結果及び考察}

表 2，表 3 にトマトとメロン各試験区のガス分析結果 及び (1)〜(4) 式より求めた呼吸量の算出結果を示した.

\section{1. 減圧試験区の分析値の信頼性}

減圧試験区の場合，チャンバ内の空気をシリンジ目盛 で $0.5 \mathrm{ml}$ サンプリングしたが, シリンジ内の実際の空 気量はサンプリング時の圧力と, 大気圧との比に比例し た量になっていると考えられる．例元ば， $\mathrm{N}_{2}$ ガスの場 合，大気圧 $(760 \mathrm{mmHg}$ ) の空気中に容積割合で $78 \%$ 含まれている5 が, 压力 $100 \mathrm{mmHg}$ では $1 / 7.6$ に希薄 されるので，大気圧に換算するとその容積割合は約 10 \%になるはずである.

ところで， $\mathrm{N}_{2}$ ガスは青果物の呼吸作用に直接関与し ないので，青果物のおかれた雾囲気中であその濃度が変 化することはないと考えられる。 そこで，これを一つの 指標として表 2 , 表 3 の減圧区の $\mathrm{N}_{2}$ ガス濃度を圧力と 
表 2 トマト各試験区の㻴境湘定結果

\begin{tabular}{|c|c|c|c|c|c|}
\hline \multirow{2}{*}{ 試 験 区 } & \multirow{2}{*}{$\begin{array}{l}\text { 分析時圧力 } \\
(\mathrm{mmHg})\end{array}$} & \multicolumn{3}{|c|}{ ガ ス 組 成 (名) } & \multirow{2}{*}{$\begin{array}{c}\mathrm{CO}_{2} \text { 排出量 } \\
(\mathrm{mg} / \mathrm{kg} \cdot \mathrm{h})\end{array}$} \\
\hline & & $\mathrm{CO}_{2}$ & $\mathrm{O}_{2}$ & $\mathrm{~N}_{2}$ & \\
\hline \multirow{7}{*}{ 差 圧 减 圧 } & 218 & 4.63 & 2.37 & 21.68 & \multirow[t]{2}{*}{0.33} \\
\hline & 275 & 6.13 & 2.47 & 27.58 & \\
\hline & 114 & 3.09 & 1.07 & 10.85 & \multirow[t]{2}{*}{0.62} \\
\hline & 258 & 5.64 & 3.00 & 25.31 & \\
\hline & 103 & 0.23 & 2.99 & 10.33 & \multirow{3}{*}{0.25} \\
\hline & 254 & 4.37 & 3.15 & 25.90 & \\
\hline & 293 & 5.62 & 2.55 & 30.38 & \\
\hline \multirow{4}{*}{ 定 王 减 圧 } & 100 & 0.09 & 2.96 & 10.11 & 0.60 \\
\hline & 90 & 0.04 & 2.56 & 9.24 & 0.25 \\
\hline & 98 & 0.09 & 2.61 & 9.97 & 0.60 \\
\hline & 80 & 0.12 & 2.31 & 8.09 & 0.81 \\
\hline \multirow{4}{*}{ デシケータ密閉 } & (1)注) & 11.80 & 8.20 & 79.10 & \multirow{4}{*}{$\begin{array}{l}4.40 \\
4.04 \\
2.82\end{array}$} \\
\hline & (2) & 15.98 & 1.83 & 81.30 & \\
\hline & (3) & 21.85 & 0.59 & 76.66 & \\
\hline & (4) & 26.62 & 0.12 & 72.36 & \\
\hline \multicolumn{2}{|c|}{ 常圧下における呼吸量 } & & & & $15 \sim 20$ \\
\hline
\end{tabular}

注) (1)眝蔵開始 2 日後 (2) 3 日後 (3)7日後 (4)10日後

表 3 メロン各試験区の環境測定結果

\begin{tabular}{|c|c|c|c|c|c|c|}
\hline \multirow{2}{*}{ 試 験 区 } & \multirow{2}{*}{$\begin{array}{c}\text { 分析時圧力 } \\
(\mathrm{mmHg})\end{array}$} & \multicolumn{3}{|c|}{ ガ ス 組 成 (96) } & \multirow{2}{*}{$\begin{array}{r}\mathrm{CO}_{2} \text { 排出量 } \\
(\mathrm{mg} / \mathrm{kg} \cdot \mathrm{h})\end{array}$} & \multirow{2}{*}{$\begin{array}{l}\mathrm{C}_{2} \mathrm{H}_{4} \text { 発生量 } \\
(\mu / / \mathrm{kg} \cdot \mathrm{h})\end{array}$} \\
\hline & & $\mathrm{CO}_{2}$ & $\mathrm{O}_{2}$ & $\mathrm{~N}_{2}$ & & \\
\hline \multirow{6}{*}{ 差 圧 減 圧 } & 160 & 0.77 & 3.87 & 16.26 & \multirow{2}{*}{0.23} & \multirow{6}{*}{$0.4 \sim 2.5$} \\
\hline & 293 & 1.05 & 7.33 & 30.18 & & \\
\hline & 253 & 0.87 & 6.63 & 25.79 & \multirow{4}{*}{0.10} & \\
\hline & 265 & 1.03 & 6.85 & 26.99 & & \\
\hline & 299 & 1.39 & 7.74 & 30.22 & & \\
\hline & 117 & 0.69 & 2.87 & 11.83 & & \\
\hline \multirow{3}{*}{ 定 圧 減 圧 } & 102 & 0.08 & 2.80 & 10.53 & 0.21 & \multirow{3}{*}{$0.3 \sim 2.2$} \\
\hline & 100 & 0.07 & 2.87 & 10.23 & 0.18 & \\
\hline & 98 & 0.16 & 2.78 & 10.22 & 0.42 & \\
\hline \multirow{2}{*}{ ポリ袋包装 } & (1) ${ }^{\text {注) }}$ & 1.93 & 18.12 & 79.05 & \multirow{2}{*}{-} & \multirow{2}{*}{$1 \sim 2 \mathrm{ppm}$} \\
\hline & (2) & 3.45 & 13.71 & 81.93 & & \\
\hline
\end{tabular}

注) (1)貯蔵開始 $18 \mathrm{~h}$ 後 (2) $65 \mathrm{~h}$ 後

の関係でみてみると, 表 4 に示したように, 分析值と理 論的に得られる值とはほぼ一致している. 従って, 分析 の結果得られた值の信頼性は高いと考えられる。

\section{2. 減圧試験区のガス分析結果}

差圧減圧区は，圧力が上昇するにつれて $\mathrm{CO}_{2}$ 濃度が 増加している。これは，呼吸作用によって排出された 
表 $4 \mathrm{~N}_{2}$ ガス分析值と計算值

\begin{tabular}{|c|c|c|}
\hline \multirow{2}{*}{$\begin{array}{c}\text { 圧 力 } \\
(\mathrm{mmHg})\end{array}$} & \multicolumn{2}{|c|}{$\mathrm{N}_{2}$ ガ ス 濃 度 $(\%)$} \\
\hline & 計算 値 ${ }^{\text {生) }}$ & 分析 値 \\
\hline 80 & 8.21 & 8.09 \\
\hline 90 & 9.24 & 9.24 \\
\hline 100 & 10.26 & 10.23 \\
\hline 117 & 12.01 & 11.83 \\
\hline 160 & 16.42 & 16.26 \\
\hline 218 & 22.37 & 21.68 \\
\hline 253 & 25.96 & 25.79 \\
\hline 299 & 30.68 & 30.22 \\
\hline
\end{tabular}

注） $78 \times$ (分析時圧力) $/ 760$ より算出

$\mathrm{CO}_{2}$ がチャンバ内に蓄積されていったためと考えられ るが, 圧力が設定値の $300 \mathrm{mmHg}$ に達すると排気が行 われ，漕度は低下している、トマトの場合, 排気直前に 約 $6 \%$ あった $\mathrm{CO}_{2}$ 漂度が排気後には $0.2 \%$ 程度になっ ており，チャンバ内に蓄積されていた $\mathrm{CO}_{2}$ の $95 \%$ 以 上は $P_{2} \longrightarrow P_{1}$ の排気の過程でチャンバ外へ排出されて いることが判った．メロンは排気サイクルの設定が 12 時間と短かったこともあって, 排気直前の $\mathrm{CO}_{2}$ 濃度が 最も高い時でも1 1.5\% 程度であった. CA 眝蔵のガ ス条件としてトマトの場合 $\mathrm{CO}_{2}=5 \sim 9 \%, \mathrm{O}_{2}=3 \sim 10 \%$, メロンの場合 $\mathrm{CO}_{2}=3 \%, \mathrm{O}_{2}=0 \sim 10 \%$ などとなってお り ${ }^{6)}$ ここれから判断してメロンでは排気サイクルを 30〜 40 時間程度に設定するのが望ましいと思われる。

一方, 定圧減圧眝蔵はトマト, メロンとも $\mathrm{CO}_{2}$ 濃度 は $0.1 \sim 0.2 \%, \mathrm{O}_{2}$ 濃度は $3 \%$ 前後とコンスタントな值 を示した。設定圧力 $(100 \mathrm{mmHg})$ から判断して $\mathrm{O}_{2}$ 荟度の分析値は妥当であると考えられる。

メロンのエチレンガス発生量は，両減圧区とも 0.5 $2.5 \mu \mathrm{l} / \mathrm{kg} \cdot \mathrm{h}$ であった. エチレンガスの発生量につい

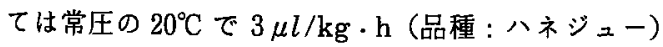
や, $16 \sim 33 \mu \mathrm{l} / \mathrm{kg} \cdot \mathrm{h}$ (品種 : カンタロープ) といった 報告があり7，品種によって值が異なっているので一概 に比較はできないが，低温・隇圧の条件である程度発生 量を抑える効果は期待できそうである.

\section{3. デシケータ密閉区及びポリフィルム包装区のガス} 組成

トマトの入ったデシケータ内は外部と空気の出入りが ないため, 販蔵日数の経過につれて $\mathrm{CO}_{2}$ 濃度が上昇し， $\mathrm{O}_{2}$ 濃度が低下していった．眝蔵 3 日目には $\mathrm{CO}_{2}$ 濃度 が $16 \%, \mathrm{O}_{2}$ 濃度が $1.8 \%$ となり， CA 眝蔵等でいわれ
ている適正ガス組成から外れた濃度になった。供武した 低密度ポリエチレンフィルムは，ガス体を透過する性質 があるため，貯蔵日数が経過してもガス組成が極端な值 となることはなかった，しかし，眝蔵８日目に行ったエ チレンガスの分析の際にエタノールが検出されており， これは減圧試験区には見られなかった現象だけに問題之 思われた。

\section{4. 呼吸量算出結果}

(1) トマトの $\mathrm{CO}_{2}$ 排出量

減圧の両区は, 差圧隇圧区で $0.3 \sim 0.6 \mathrm{mg} / \mathrm{kg} \cdot \mathrm{h}$, 定圧隇圧区で 0.3 0.8 mg/ $\mathrm{kg} \cdot \mathrm{h}$ とほぼ同様の值であ った。これに対し，デシヶー夕密閉区は $3 \sim 4 \mathrm{mg} /$ $\mathrm{kg} \cdot \mathrm{h}$, 常压下では $15 \sim 20 \mathrm{mg} / \mathrm{kg} \cdot \mathrm{h}$ で, 減圧区に比 ベてそれぞれ 7〜8倍，30〜40 倍の呼吸量になっており， 減圧による呼吸作用の㧕制効果が顕著であった。

(2) メロンの $\mathrm{CO}_{2}$ 排出量

メロンはトマトに比べると呼吸量は小さく，減圧区で $0.1 \sim 0.4 \mathrm{mg} / \mathrm{kg} \cdot \mathrm{h}$ であった，常圧下では 4 5 mg/ $\mathrm{kg} \cdot \mathrm{h}$ であるこよから，やはり減圧による呼吸作用の 抑制効果は大きかった。

\section{要約}

トマトとメロンを供試して，眝蔵中の隇圧下のチャン バ内ガス組成を分析した。 また，その結果をもとに減圧 下における両品目の呼吸量を算出した，まず，減圧下の チャンバ内から直接空気をサンプリングするための器具 を試作し，この器具を介してガスタイトシリンジでサン プリングを行った，サンプリングしたガスをガスクロマ トグラフにかけて, $\mathrm{O}_{2}, \mathrm{CO}_{2}, \mathrm{~N}_{2}$ 及び $\mathrm{C}_{2} \mathrm{H}_{4}$ について それぞれ分析を行った。

分析値をもとに両品目の呼吸量 $\left(\mathrm{CO}_{2}\right.$ 排出量) を算 出した結果，トマトは減圧下では常圧下の 1/30〜 1/40, メロンも同様に $1 / 20$ 程度の呼吸量になっており，隇圧 による呼吸作用の抑制効果は顕著であった。

なお，本研究を進める上でエチレンガスの分析に際し ては, 農林水産省食品総合研究所に多大のご協力をいた だいた.ここに記して謝意を表する。

\section{文献}

1）小野田明彦 - 小泉武紀 - 山本健司 - 古谷 正 - 山 川秀人・小川浄寿：日食工誌，投稿中.

2) Wu, M.T., Jadhav, S.J. and SALunkHe, D.K. : J. Food Sci., 37, 952 (1972). 
3）近藤 悟 - 大垣智昭 - 金 珢 : 園学雑, 52 , 180 (1983).

4) 上田悦範 - 中本昌利 - 緒方邦安 : 日食工誌，27, (1980).

5）中川 洋 : 真空技術入門，(朝倉書店，東京)，p.
16 (1967).

6) 田村 勉: 青果保蔵汎論, 緒方邦安編（建帛社, 東京), p. 203 (1977).

7) 中馬 豊: 食品工業, 24 (12), 29 (1981).

(昭和 63 年 5 月 12 日受理)

\title{
新刊紹介
}

Fat-Soluble Vitamin Assays in Food Analysis -A Comprehensive Review-

\author{
G.F.M. BALL 著
}

本書は脂溶性ビタミン， A， D， E，および K につ き，化学的 - 生物学的性質について解説 (50 頁) L, 食品分析としての必要性, 前処理法 (クリーンアップを 含む， 40 頁)，古典的ではあるが，吸光法，䖵光法等に よる個別の全量湘定法, ガスクロマトグラフ法, そして 現在, 最むよく用いられるようになった高速液体クロマ トグラフ法について詳細に記述している(約 150 頁). 文献網羅的ではなく，実際に測定する立場に立った実験 書としての解説であり，食品の実例が豊富である．文献 約 350 篇 (1987 年まで).

$23 \times 14.7 \mathrm{~cm}, 324$ 頁, 45 ポンド

Elsevier Science Publishers Ltd., Crown House, Linton Road,

Barking, Essex IG11 8 JU, England 